\title{
Juvenile chronic arthritis, chronic iridocyclitis, and reactivity to histones
}

\author{
Alison M Leak, Patricia Woo
}

Autoimmune rheumatic diseases in childhood present major differences in both clinical and laboratory features compared with adult onset disease. ${ }^{1}$ Although polyarthritis occurs in both adults and children, the specific features of seropositive erosive rheumatoid arthritis are only seen in about $10 \%$ of patients with juvenile chronic arthritis beginning under the age of 16 years. ${ }^{12}$ Most have seronegative disease-that is, without IgM rheumatoid factor, and serologically the more common finding is of antinuclear antibodies. These antibodies are detected in $30-40 \%$ of all children with juvenile chronic arthritis, but are most common in late onset seropositive polyarthritis and in early onset pauciarticular disease. ${ }^{3-5}$ These latter children with four or fewer joints affected in the first three months commonly have a limited arthritis, and with appropriate management usually have little long term disability. In antinuclear antibody positive pauciarticular arthritis beginning under the age of 5 years, however, $60-70 \%$ of children develop chronic iridocyclitis, which may cause blindness, ${ }^{6}$ and around $80 \%$ of those affected are girls. ${ }^{7}$

It is not clear whether chronic anterior uveitis is an autoimmune disorder or an immune complex vasculitis. ${ }^{8}$ The initial cause of tissue damage may be physical trauma, infection, chemical, or immunological injury. Uveal damage caused by viruses or other microbial organisms may expose antigens, normally contained within cells, for subsequent autoimmune sensitisation.

After an initial attack of uveitis it has been postulated that the endothelial lining of the uveal blood vessels may become permanently damaged, thereby reducing the effectiveness. of the blood/aqueous barrier. ${ }^{9}$ This would allow deposition of specific antinuclear antibody/ antigen complexes or the later deposition of unrelated immune complexes, which would then cause a recrudescence and perpetuation of inflammation. ${ }^{9-11}$ The rich blood supply of the uvea may trap immune complexes, and in nongranulomatous uveitis these are thought to be only moderate in size. Evidence for immune complex formation in pauciarticular juvenile chronic arthritis is limited, however. ${ }^{12-15}$ Lack of lymphatic drainage to the eye reduces sequestration and processing of antigen by lymphoid tissue in peripheral nodes. ${ }^{16}$ Primed lymphocytes return to the uvea and production of antibody occurs locally. ${ }^{9}$

The antigenic stimulus to antinuclear antibody formation in both adult rheumatoid arthritis and in juvenile chronic arthritis is unknown. Antinuclear antibodies are detectable on both HEp-2 cells and on rodent tissue substrate. The pattern of immunofluorescence may be speckled, ${ }^{17}$ but is usually homogeneous, ${ }^{41819}$ and suggests binding to the nucleosome, in which histones and DNA exist in a highly organised structure. ${ }^{20}$ Many authors have reported the uncommon existence of antibodies to double stranded DNA. ${ }^{21-26}$ Antibodies to single stranded DNA, though detectable in active juvenile chronic arthritis, ${ }^{19} 27$ are also found in many other disorders and their pathogenic significance is uncertain. ${ }^{24}$ Also, none of the well characterised autoantibodies found in connective tissue diseases (including antibodies to Ro, La, RNP, Sm, PM-1, Scl-70) is present with any regularity. $172125 \quad 28-30$

Attention recently has shifted towards further evaluation of antibodies to histones, and several authors have reported the presence of these antibodies in juvenile chronic arthritis. ${ }^{31-38}$

\section{Histones}

Histones are basic DNA binding proteins, which are arranged in a highly organised structure in nucleosomal particles, subcomponents of chromatin. A double loop of DNA (200 bp long) is wound round two $\mathrm{H} 2 \mathrm{~A}-\mathrm{H} 2 \mathrm{~B}$ dimers on either side of the (H3-H4) 2 tetramer in the core of the particle ${ }^{20} 39$ (figure). The association of the core histones with DNA causes a condensation of the double helix, which is further compacted by the binding of $\mathrm{Hl}$ in a second order supercoil. ${ }^{39}$ This organisation of the nucleosome allows separation of individual

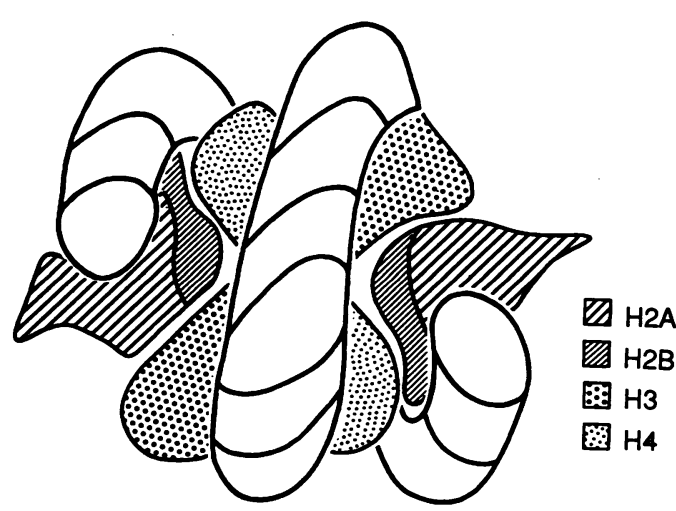

A single nucleosome showing the relation between the various histone molecules within two helical turns of DNA (adapted from ref 39). 
chromosomes at mitosis and contributes to polymorphisms of the DNA structure. ${ }^{39}$

$\mathrm{H} 3$ and $\mathrm{H} 4$, forming the inner relatively inaccessible core of nucleosomes, are evolutionarily highly conserved. ${ }^{40}$ Differences between calf and pea plant histones $\mathrm{H} 3$ and $\mathrm{H} 4$ are limited to four substitutions out of 135 amino acid residues for $\mathrm{H} 3$, and two of 102 residues for $\mathrm{H} 4 .^{39} \mathrm{H} 2 \mathrm{~A}$ and $\mathrm{H} 2 \mathrm{~B}$ also show major similarities between calf and human sources. This conservation of structure has been thought to be responsible for the poor immunogenicity of core histones. ${ }^{41}$ Only certain regions of each histone molecule are exposed on the surface of the particle, and it is thought that most antibodies to histones in systemic rheumatic diseases are directed to exposed parts of the histone molecule-that is, these antibodies are induced by epitopes on the intact nucleosomal particle. ${ }^{41-43}$

\section{Techniques for the detection of antibodies to} histones

As with any investigation of antigen reactivity it is important to analyse the test systems used and to understand their limitations. Although antibodies reactive to histone were reported in $1958,{ }^{44}$ reinvestigation of their antigenicity did not take place until 1976, when Tan and colleagues introduced the acid elution/reconstitution method for their detection. ${ }^{45}$ Serum samples positive for antibodies to histones, which are antinuclear antibody positive by immunofluorescence, will become negative after acid elution of the substrate, and reconstitution with histones then reproduces the positive fluorescence. Although initially heralded as a specific and reproducible assay, several methodological problems limit its use. ${ }^{46}$ Histones $\mathrm{H} 2 \mathrm{~A}$ and $\mathrm{H} 2 \mathrm{~B}$ are most commonly detected by this method, even though the same serum samples may be positive for other histones by other tests. ${ }^{42} 4347$ The reason may be that $\mathrm{H} 3$ and $\mathrm{H} 4$ epitopes, which are prerequisites for binding of the H2A-H2B dimers, become concealed by DNA binding to $\mathrm{H} 2 \mathrm{~A} / \mathrm{H} 2 \mathrm{~B}$ in the reconstitution phase. ${ }^{42}$ Variability between laboratories is also likely because immunofluorescence is a subjective assay open to observer error. ${ }^{48}$

A further technique for antigen detection and analysis was described in 1979 by Towbin. ${ }^{49}$ Immunoblotting or western blotting was originally used to detect very small amounts of ribosomal protein after transference from the gel phase of electrophoresis to a solid phase for immunoreaction with antisera. In general, blotting has been accepted as a useful technique for detecting autoantibodies. ${ }^{50}$ The use of sodium dodecyl sulphate in the gel electrophoresis before transference onto nitrocellulose may cause denaturation of histones and has been said to interfere with histone-antibody complex formation. ${ }^{43}$

In rheumatoid arthritis and the equivalent disease in children, seropositive juvenile arthritis, up to $30 \%$ of patients may be antinuclear antibody positive. When investigating these patients by immunoblotting it is possible that some of the lines recognised may be false positive reactions related to circulating immune complexes. ${ }^{48}$ Rheumatoid factors may bind to specific IgG antihistone antibodies or directly to histone, ${ }^{51}$ and Gripenberg reported that some antihistone activity is due to cross reacting rheumatoid factors. ${ }^{52}$ Analysis of reactivity to histones in seropositive juvenile arthritis is limited, and no profile of reactivity to the different histone classes has yet emerged.

Development of solid phase assays was initially difficult owing to problems of immobilisation of cationic histone antigens. ${ }^{46} \mathrm{~A}$ fluorimetric assay was used by Hobbs et al to detect antibodies to histones using purified histones, ${ }^{53} 54$ and found to be more sensitive than the acid elution/ reconstitution method. Non-specific antibody binding is reduced by histone saturation of the tyrosine-glutamic acid copolymer coating the cuvettes. ${ }^{53}$ This copolymer, which increases the sensitivity of the assay, may affect the conformation of histone $\mathrm{H} 4$ and reduce detection of anti-H4. ${ }^{51}$

An enzyme linked immunosorbent assay (ELISA) can offer a quantitative analysis and seems to be the method of choice for investigating different conformational states of chromatin. ${ }^{55}$ As with blotting, considerable differences are seen in the apparent antigenic activity of different histones depending on the assay. ${ }^{37}$ Purified immunoreactive histones are essential for meaningful and reproducible results. ${ }^{48}$ The heterogeneity of antihistone antibody reactivity may reflect mixtures of antibodies to individual histones, or antigenic cross reactivity.

Clinical associations of antibodies to histones In adult rheumatoid arthritis, using the technique of acid elution/reconstitution, Aitcheson et al demonstrated antibodies to histones in $24 \%$ of antinuclear antibody positive patients. ${ }^{56}$ In a study by Epstein et al, using unfractionated histones in an ELISA, ${ }^{46}$ antibodies to histones were detected in $100 \%$ of patients with drug induced systemic lupus erythematosus, in $42 \%$ with idiopathic systemic lupus erythematosus, but in only $15 \%$ of adults with rheumatoid arthritis, and at very low concentrations, compared with one of 24 healthy control subjects. With a more sensitive ELISA (Nucleoscreen kit-see below), however, Muzellec et al found that $80 \%$ of antinuclear antibody positive patients with rheumatoid arthritis had antibodies to histones, of which antibodies to $\mathrm{Hl}$ were most common, being significantly more prevalent than in controls. ${ }^{57}$ Patients treated with D-penicillamine had a significantly higher concentration of antibodies to histone $\mathrm{Hl}$ than those not so treated.

With acid elution/reconstitution we were only able to detect antibodies to histones in two of 15 patients with antinuclear antibody positive juvenile chronic arthritis. Both were girls with extended pauciarticular arthritis complicated by severe chronic iridocyclitis (Leak A M, MD thesis, London, 1991). Similarly, Rosenberg, ${ }^{25}$ Saulsbury, ${ }^{30}$ and Haynes $^{19}$ found only $0-10 \%$ of children with antinuclear antibody positive juvenile chronic arthritis possessed antibodies to histones by this 
method. Job-Deslandre et al, however, used a total histone ELISA (calf thymus) to. test a spectrum of rheumatic diseases in children and detected antibodies to histones in 23 of $39(59 \%)$ children with juvenile chronic arthritis, of whom most of the children with antibodies to histones had a pauciarticular onset. ${ }^{35}$ Antibodies to histones were also found in a significant number of children with other inflammatory conditions (42\%), including infections, and in between 14 and $20 \%$ of children not usually possessing autoantibodies-for example, patients with irritable hip and mechanical musculoskeletal problems. In the subgroup of patients with juvenile chronic arthritis with an age of onset of under 5 years antihistone antibody concentrations were significantly higher than in control groups.

Four groups reported the use of immunoblotting to characterise the antinuclear antibodies found in juvenile chronic arthritis. ${ }^{31-34}$ All the groups studied mixed seronegative types of juvenile chronic arthritis, about half with polyarticular and half with pauciarticular disease. The children chosen for analysis had a high prevalence of positive antinuclear antibodies by immunofluorescence of $\mathrm{HEp}-2$ cells $(70-100 \%$ positive at 1:20 dilution). A preliminary study by Brunet in 1986 suggested that six of nine children tested had antibodies to histones thought to be directed against H2B. ${ }^{31}$ More recently, Malleson, ${ }^{32}$ Pauls, ${ }^{33}$ and Rosenberg ${ }^{34}$ have detected bands by immunoblotting which were thought to represent histone $\mathrm{Hl}$. These were found in $42 \%, 35 \%$, and $37 \%$ of their patients respectively. In addition to $\mathrm{Hl}$, Malleson's group reported that $12 \%$ of patients had a band identified at $45 \mathrm{kD}$ which was specifically not associated with iridodcyclitis. ${ }^{32}$ Pauls noted that many patients with $\mathrm{Hl}$ also had antibodies to $\mathrm{H} 5$, a variant of $\mathrm{H} 1,{ }^{33}$ whereas the intensity of reaction with core histones was much weaker, and Rosenberg reported that although many bands were seen on immunoblotting as well as the $33 \mathrm{kD}$ band thought to be $\mathrm{H} 1$, a similar spectrum of bands was also seen in patients without juvenile chronic arthritis who were analysed as contròls. ${ }^{34}$

Newer ELISA techniques have been developed by Muller and colleagues in which antibodies to each of the histone classes can be detected independently using purified histones from chicken erythrocytes for the four core histones and calf thymus for $\mathrm{Hl}$ (Nucleoscreen kit, Neosystem, Strasbourg ${ }^{57}$ ).

Three studies have been performed in children with juvenile chronic arthritis with the Nucleoscreen ELISA. Ostensen reported results on a group of 121 patients with juvenile chronic arthritis, 72 pauciarticular and 49 either polyarticular or systemic onset. ${ }^{36}$ A total of 58 patients had antibodies to histones, including 21 with antibodies to H1. Among the children with antibodies to histones there was a strong association with antibodies to $\mathrm{H} 3$ in 26 of 28 (93\%) patients who had chronic iridocyclitis compared with 14 of $30(47 \%)$ anti-H3 positive patients without eye disease. Children without eye disease had a more homogeneous response to all histones rather than a peak for $\mathrm{H} 3$ seen in children with uveitis. No associations were seen in either this, or the other reported studies using immunoblotting, ${ }^{32} 33$ between antibodies to histones and clinical disease activity, median antinuclear antibody titres, or drug treatment. Recent analysis by Tuaillon $e t$ al of a further group of unselected children with juvenile chronic arthritis (14 pauciarticular onset, 18 polyarticular or systemic) again shows reactivity to histones of all types, with antibodies to $\mathrm{H} 1$ and $\mathrm{H} 3$ being most often detected. ${ }^{37}$ Insufficient clinical details were available to test for associations with disease activity or with chronic iridocyclitis.

We recently analysed antibodies to histones by an ELISA in collaboration with Muller in 44 patients selected because of early onset (mean three years, all less than eight years) pauciarticular juvenile chronic arthritis. ${ }^{38}$ Previous work suggested that the highest antinuclear antibody titres seen in this subgroup of diseases are found in the first few months of the disease ${ }^{18}$ and, therefore, particular attention was paid to collecting early serum samples. In addition, serial samples were collected from 32 children. Thirty five of 44 were girls, and 23 had developed chronic iridocyclitis. IgM antihistone antibodies were found in $75 \%$ of the patients and antibodies to $\mathrm{H} 3$ were the most common (in $56 \%$ ) followed by $\mathrm{Hl}$ (49\%), H2A (49\%), H4 (46\%), and anti-H2B (37.5\%).

Assessment of clinical variables showed an association of antibodies to histone $\mathrm{Hl}$ with joint score, erythrocyte sedimentation rate, and IgG $(p=0.05)$ and with antinuclear antibody titres $(p=0.001)$. Regression of disease activity from year 1 to years 2 and 3 was paralleled by a significant fall in antibodies to $\mathrm{H} 1$ and $\mathrm{H} 2 \mathrm{~A}$, while anti-H3 remained high. There was no association of antibodies to histones with either the presence or degree of activity of chronic anterior uveitis, and no clinical associations with antibodies to $\mathrm{H} 3$ were found despite their frequent occurrence. The disparity between these results and Ostensen's study may be due to differences in the duration of disease. More of our patients, still early in the disease course, may develop uveitis over the next two to three years, though after that additional numbers are likely to be small. Will raised anti-H3 concentrations be a marker for eye disease?

Further analysis of reactivity to 32 synthetic histone peptides was made according to the technique described by Tuaillon et al. ${ }^{37}$ The most commonly recognised peptides were to the $\mathrm{N}$-terminal regions of $\mathrm{H} 2 \mathrm{~A}$ and $\mathrm{H} 3$ and the $\mathrm{C}$ terminal peptides of $\mathrm{Hl}$ and $\mathrm{H} 3$. Thus 29 of our 44 patients had IgG antibodies to either one or other of the $\mathrm{H} 3$ peptides (amino acid residues 1-21, 130-135). When anti-H3 peptide positive serum samples were compared with $\mathrm{H} 3$ peptide negative samples the former were significantly more likely to be associated with positive antinuclear antibodies $(58 \% v 7 \%, \mathrm{p}=0.001)$ or with chronic iridocyclitis $(69 \% v 29 \%, p=0.008)$.

Tuaillon et al used the same technique of peptide analysis in juvenile chronic arthritis and again detected significant reactivity to $\mathrm{H} 3$ peptides, but also to the $\mathrm{N}$-terminal peptide of H4. ${ }^{37}$ The authors noted a poor correlation between $\mathrm{H} 3$ histone and $\mathrm{H} 3$ peptide anti- 
bodies, ${ }^{37}$ and our results corroborate this finding.

\section{Antibodies to histones and chronic iridocyclitis}

The association of antinuclear antibodies with chronic anterior uveitis has been clinically reported for nearly 20 years, but a pathogenic role for the antinuclear antibody remains elusive. Antibodies to histones have now been shown most commonly in the early onset pauciarticular subgroup of juvenile chronic arthritis, who are susceptible to uveitis. Clinical associations with eye disease seem to be strongest with antibodies to $\mathrm{H} 3,{ }^{36}{ }^{38}$ though it is not known whether antibodies to intact $\mathrm{H} 3$ molecules are the same as those reacting with synthetic $\mathrm{H} 3$ peptides.

The chronic iridocyclitis of juvenile chronic arthritis is unique and there is no exact experimental model of this non-granulomatous anterior uveitis, especially in relation to the chronic relapsing course. Petty studied the uveitis of adjuvant induced arthritis in rats, the nearest animal model. Antibodies to bacterial components, ocular and articular antigens, did not correlate with uveitis. ${ }^{58}$

Experimental autoimmune uveitis (an acute anterior and posterior uveitis) without arthritis can be induced in laboratory animals by retinal $S$ antigen, ${ }^{59}$ and one of the sequences of this protein, known to be uveito-pathogenic (amino acids 303-320), has a similar sequence to a variety of proteins. ${ }^{60}$ The best match is with amino acids 106-121 from baker's yeast histone H3. Singh et al were able to induce experimental autoimmune uveitis in Lewis rats by injection of this histone peptide. ${ }^{60}$ We were unable to find any patients with antibodies to $\mathrm{H} 3$ peptide 98-112, which has the closest homology to the S antigen peptide 303-320. This synthetic $\mathrm{H3}$ peptide has also been tested in an experimental uveitis system with negative results (Graham E, personal communication).

The pathogenetic mechanism proposed by Singh et al was one of molecular mimicry, which might explain the development of autoimmune chronic uveitis, whereby immune response is initially directed against the antigen in the yeast histone, and persists because of shared determinants with host retinal S antigen. ${ }^{60}$ Molecular mimicry has been proposed for other sequence homologies linking the retrovirus, visna, with experimental allergic encephalitis (the animal model of multiple sclerosis), a human adenovirus with $\alpha$-gliadin in the production of coeliac disease, and shared epitopes between HLA-B27 and Klebsiella pneumoniae nitrogenase. ${ }^{60}$ Induction of any of these diseases by specific microbial agents may occur in a susceptible subject. In the uveitis model yeast histones are implicated as the possible initiators of the autoimmune inflammation.

One significant aspect of chronic iridocyclitis in juvenile chronic arthritis is that it is most common in girls and in children with an age of onset between the first and third birthday (42 of $73(58 \%)$ affected in one study) (Leak A $M$, MD thesis, London, 1991). Eye disease is very uncommon if juvenile chronic arthritis begins after the age of 5 years ( $7 \%$ of cases) (Leak A M, MD thesis, London, 1991), though the uveitis itself may not become manifest until many years later. The eye is, in fact, relatively fully developed at birth and three quarters of all subsequent development takes place in the first three years of life. Perhaps it is only at this stage that an initiating event may occur which subsequently in a susceptible subject could lead directly to perpetuation of the inflammatory response.

There is strong evidence for genetic association with this form of juvenile chronic arthritis, ${ }^{61-63}$ predominantly with the HLA class II genes. Production of antinuclear antibodies and antibodies to histones may be a further characteristic of this impaired or altered immune response. The question of whether these antibodies are directly concerned with the pathogenesis of the eye disease remains to be tested.

1 Leak A M, Isenberg D A. Autoimmune rheumatic disorders in childhood - a comparison with adult onset disease. $Q \mathcal{F}$ Med 1989; 73: 875-993.

2 Ansell B M. Juvenile chronic arthritis with persistently positive tests for rheumatoid factor. Ann Pediatr (Paris) 1983; 30: 545-50.

3 Petty R E, Cassidy J T, Sullivan D B. Clinical correlates of antinuclear antibodies in juvenile rheumatoid arthritis. f Pediatr 1973; 83: 386-9.

4 Kornreich H K, Drexler E, Hanson V. Antinuclear factors in childhood rheumatic diseases. I Pediatr 1966; 69: 1039-45.

5 Schaller J G, Johnson G D, Holborow E J, et al. The association of antinuclear antibodies with the chronic association of antinuciear antibodies with the chronic iridocyclitis of juvenile rheumatoid
Arthritis Rheum 1974; 17: 409-16.

6 Kanski J J. Anterior uveitis in juvenile rheumatoid arthritis. Arch Ophthalmol 1977; 95: 1794-7.

7 Rosenberg A M. Uveitis associated with juvenile rheumatoid arthritis. Semin Arthritis Rhewm 1987; 16: 158-73.

8 Merriam J C, Chylack L T, Albert D M. Early-onset pauciarticular juvenile rheumatoid arthritis. A histopathological study. Arch Ophthalmol 1983; 101: 1085-92.

9 Rahi A H S, Kanski J J, Fielder A. Immunoglobulins and antinuclear antibodies in aqueous humour from patients with juvenile "rheumatoid" arthritis (Still's disease). Trans With juvenile "rheumatoid" arthritis (S

10 Petty R E. Current knowledge of the aetiology and pathogenesis of chronic uveitis accompanying juvenile rheumatoid genesis of chronic uveitis accompanying juvenile rheumatoi

11 Char D H, Stein P, Masi R, Christensen M. Immune complexes in uveitis. Am $\mathcal{F}$ Ophthalmol 1979; 87: 678-81.

12 Rossen R D, Brewer E J, Person D A, et al. Circulating immune complexes and antinuclear antibodies in juvenile rheumatoid arthritis. Arthritis Rheum 1977; 20: 1485-90.

13 Miller J J, Osborne C L, Hsu Y P. Clq binding in serum in juvenile rheumatoid arthritis. F Rheumatol 1980; 7: 665-70.

14 Balogh Z, Merétey K, Falus A, Bozsóky S. Serologic abnormalities in juvenile chronic arthritis: a review of 46 cases. Ann Rheum Dis 1980; 39: 129-34.

15 Egeskjold E M, Johansen A, Permin H, Høyeraal H M Sørensen $T$. The significance of antinuclear antibodies in Sorensen $T$. The significance of antinuclear antibodies in bilateral iridocyclitis. Acta Paediatr Scand 1982; 71: 615-20. bilateral iridocyclitis. Acta Paediatr Scand 1982; 71: 615-20.
Chader G. Biochemistry of the eye. In: Miller S, ed. Clinical 16 Chader G. Biochemistry of the eye. In: Miller S
ophthalmology. Bristol: Wright, 1987: $24-45$.

17 Osborn T G, Patel N J, Moore T L, Zuckner J. Use of the HEp2 cell substrate in the detection of antinuclear antibodies in juvenile rheumatoid arthritis. Arthritis Rheum 1984; 27: 1286-9.

18 Leak A M, Burman S J, Ansell B M. Antinuclear antibody studies in juvenile chronic arthritis. Arch Dis Child 1986; 61: $168-72$.

19 Haynes D C, Gershwin M E, Robbins D L, Miller J J, Cosca $D$. Autoantibody profile in juvenile arthritis. $\mathcal{f}$ Rheumatol 1986; 13: 358-63.

20 Richmond T J, Finch J T, Rushton B, Rhodes D, Klug A Structure of the nucleosome core particle at $7 \AA$ resolution Structure of the nucleosome

21 Alspaugh $M$ A, Miller J J. A study of specificities of antinuclear antibodies in juvenile rheumatoid arthritis. f Pediatr 1977; 90: 391-5.

22 Rudnicki R D, Ruderman M, Scull E, et al. Clinical features and serological abnormalities in juvenile rheumatoid arthritis. Arthritis Rheum 1974; 17: 1007-15.

23 Permin H, Halberg P, Christiansen E. Antibodies against dsDNA in patients with connective tissue disorders. Acto Med Scand 1978; 203: 61-5.

24 Cassidy J T, Walker S E, Soderstrom S J, Petty R E, Sullivan $D$ B. Diagnostic significance of antibody to native DNA in children with juvenile chronic arthritis. F Pediatr 1978; 93 : 416-20.

25 Rosenberg A M, Cordeiro D M, Knause R P. Studies on the specificity of antinuclear antibodies (ANA) in juvenile rheumatoid arthritis [abstract]. Arthritis Rheum 1983; 26: rheu.

26 Bell C, Talal N, Schur P. Antibodies to DNA in patients with rheumatoid arthritis and juvenile rheumatoid arthritis. rheumatoid arthritis and juvenile 
27 Leak A M, Colaco C B, Isenberg D A, Dudeney C, Burman S J, Ansell B M. Anti-cardiolipin and anti-ssDNA antibodies in ANA positive juvenile arthritis and other rheumatic diseases [abstract]. Clin Exp Rheumatol 1987; 5 (suppl 2): diseases.

28 Leak A M. Autoantibody profile in juvenile chronic arthritis [review]. Ann Rheum Dis 1988; 47: 178-82.

29 Siamopoulos-Mavrides A D, Mavrides A K. Antinuclear antibodies in Greek juvenile arthritis patients. Clin Exp Rheumatol 1984; 3: 362-3.

30 Saulsbury F T. Antinuclear antibody specificity in juvenile chronic arthritis. Clin Res 1985; 33: 512a.

31 Brunet C, Craft J, Nakamura M, Pachman L, Athreya B, Hardin J. Identification of nuclear antigens bound by sera from patients with juvenile rheumatoid arthritis [abstract]. Arom patients with juvenile rhe

32 Malleson $\mathbf{P}$ N, Petty $R$ E, Fung $M$, Candido E P M Reactivity of antinuclear antibodies with histones and other antigens in juvenile rheumatoid arthritis. Arthritis Rheum 1989; 32: 919-23.

33 Pauls J D, Silverman E, Laxer R M, Fritzler M J. Antibodies to histones $\mathrm{Hl}$ and $\mathrm{H} 5$ in sera of patients with juvenile rheumatoid arthritis. Arthritis Rheum 1989; 32: 877-83.

34 Rosenberg A M, Prokopchuk P A. Antibodies to HEp2 nuclei in juvenile rheumatoid arthritis (JRA) analysed by

35 Job-Deslandre C, Kapel N, Weill B J, Maheu E, Menkes C J Etude des anticorps antinucleaires et anti-histones au coms de l'arthrite chronique juvenile. Rev Rhum Mal Osteoartic 1989; 56: 31-3.

36 Ostensen M, Fredriksen K, Kass E, Rekvig O-P. Identification of antihistone antibodies in subsets of juvenile chronic arthritis. Ann Rhewm Dis 1989; 48: 114-7.

37 Tuaillon N, Muller S, Pasquali J-L, et al. Antibodies from patients with rheumatoid arthritis and juvenile chronic arthritis analysed with core histone synthetic peptides. In Arch Allergy Appl Immunol 1990; 91: 297-305.

38 Leak A M, Muller S, Tuaillon N, Woo P. Reactivity to histones and histone peptides in early onset pauciarticular juvenile chronic arthritis [abstract]. Br $\mathcal{F}$ Rheumatol 1989; 28: 104 .

39 Burlingame R W, Love W E, Wang B C, Hamlin R, Nguyen H X, Moudrianakis E N. Crystallographic structure of the H X, Moudrianakis E N. Crystallographic structure of the octameric histone cores of the nucleo
3.3A. Science 1985; 228: 546-53.

40 Rubin P L. In: Lahita R G, ed. Antihistone antibodies in systemic lupus erythematosus. USA: Wiley, 1987: 271-89.

41 Muller S, Van Regenmortel H M V. Specificity of antihistone antibodies in systemic rheumatic disease. International fournal of Immunopathalogy and Pharmacolog 1988; 1: 139-48.

42 Gohill J, Cary P D, Couppez M, Fritzler M J. Antibodies from patients with drug-induced and idiopathic lupus erythematosus react with epitopes restricted to the amino and carboxyl terminus of histone. $\mathcal{F}$ Immunol 1985; 135: and carboxy

43 Portanova J P, Arndt R E, Tan E M, Kotzin B L. Antihistone antibodies in idiopathic and drug-induced lupus recognise distin

44 Friou G J. Identification of the nuclear component of the interaction of lupus erythematosus globulin and nuclei. f Immunol 1958; 80: 476-81.

45 Tan E M, Robinson J, Robitaille P. Studies on antibodies to histones by immunofluorescence. Scand $\mathcal{F}$ Immunol 1976 5: 811-8.
46 Epstein A, Greenberg M, Halbert S, Kramer L, Barland P. The clinical application of an ELISA technique for the detection of anti-histone antibodies. $\mathcal{F}$ Rheumatol 1986; 13: 304-7.

47 Rubin R L, McNally E M, Nusinow S R, Robinson C A, Tan E M. IgG antibodies to the histone complex H2A-H2B characterise procainamide-induced lupus. Clin Immuno Immunopathol 1985; 36: 49-59.

48 Costa O, Monier J-C. Anti-histone antibodies detected by ELISA and immunoblotting in systemic lupus eryth ematosus and rheumatoid arthritis. F Rhermatol 1986; 13 : $722-5$.

49 Towbin H, Staehelin T, Gordon J. Electrophoretic transfer of proteins from polyacrylamide gels to nitrocellulose sheets: procedure and some applications. Proc Natl Acad Sci USA procedure and som

50 Maini R N, Charles P J, Venables P J. Antinuclear antibodies in the immunotaxonomy of connective tissue disorders. in the immunotaxonomy of connective tiss

51 Bernstein R M, Hobbs R N, Lea D S, Ward D J, Hughes G R V. Patterns of anti-histone antibody specificity in systemic rheumatic disease. Arthritis Rheum 1985; 28 285-93.

52 Gripenberg M, Helve T, Kurki P. Profiles of antibodies to histones, DNA and IgG in patients with systemic rheumatic diseases determined by ELISA. $\mathcal{f}$ Rheumatol 1985; 12 : 934-9.

53 Hobbs R N, Lea D J, Ward $\mathrm{D}$ J. Fluorimetric assay tor human antibodies to all the histones. 7 Immunol Methods 1983; 65: 235-43.

54 Hobbs R N, Clayton A- L, Bernstein R M. Antibodies to the five histones and poly(adenosine diphosphate-ribose) in drug induced lupus: implications for pathogenesis. Ann Rheum Dis 1987; 46: 408-16.

55 Romac J, Bouley J P, Van Regenmortel M H V. Enzymelinked immunosorbent assay in the study of histone antigens and nucleosome structure. Anal Biochem 1981 113: $366-71$

56 Aitcheson C T, Peebles C, Joslin F, Tan E M. Characteristics of antinuclear antibodies in rheumatoid arthritis. Arthritis Rheum 1980; 23: 528-38.

57 Muzellec Y , LeGoff $P$, Jouquan J, Fauquert P, Muller S, Youinon P. Antibodies to histones in rheumatoid arthritis. Diagn Clin Immunol 1988; 5: 326-31.

58 Petty R E Johnston W Rootman J, Rollins D F. Uveitis and arthritis induced by adjuvant: clinical, immunologic and histologic characteristics. F Rheumatol 1989; 16: 499-505.

59 Nussenblatt R B, Gery I, Ballantine E J, Wacker W B. Retinal $S$ antigen and uveitis. Am $\mathcal{F}$ Ophthalmol 1980; 89: 173-9.

60 Singh V K, Yamaki K, Donoso L A, Shinohara T. Molecular mimicry. Yeast histone $\mathrm{H} 3$-induced experimental autoimmune uveitis. F Immunol 1989; 142: 1512-7.

61 Glass D, Litvin D, Wallace K, et al. Early-onset pauciarticular juvenile rheumatoid arthritis associated with human leukocyte antigen DRw5, iritis and antinuclear antibody. $f$ Clin Invest 1980; 66: 426-9.

62 Hall P J, Burman S J, Laurent M R, et al. Genetic susceptibility to early onset pauciarticular juvenile chronic arthritis: a study of HLA and complement markers in 158 British patients. Ann Rheum Dis 1986; 45: 464-74.

63 Begovich A B, Bugawan T L, Nepom B S, et al. A specific HLA-DP $\beta$ allele is associated with juvenile rheumatoid arthritis, but not adult rheumatoid arthritis. Proc Natl Acad Sci USA 1989; 86: 9489-93. 